\title{
Mats of colourless sulphur bacteria. I. Major microbial processes
}

\author{
Tom Fenchel*, Catherine Bernard ${ }^{* *}$ \\ Marine Biological Laboratory, University of Copenhagen, Strandpromenaden 5, DK-3000 Helsingor, Denmark
}

\begin{abstract}
Mats of colourless sulphur bacteria from 2 marine sediments were studied with respect to sulphide and oxygen fluxes, rates of key microbial processes and spatial and temporal heterogeneity. In a relatively protected habitat dominated by Beggiatoa species, about $70 \%$ of the sediment $\mathrm{O}_{2}$-consumption could be accounted for by the oxidation of $\mathrm{S}^{2-}$ to $\mathrm{SO}_{4}{ }^{2-}$, about $15 \%$ by food chains fuelled by chemoautotrophic production, while the remainder was due to aerobic processes not directly associated with the sulphur cycle. In this sediment about $85 \%$ of the allochthonous and autochthonous (phototrophic and chemotrophic production) organic carbon was mineralised anaerobically. The other habitat was a shallow bay which is of ten subject to wave-induced transport and erosion of the sediment. From autumn to spring, sediment surface communities of colourless sulphur bacteria were patchy in time and space and thcy represented different successional stages with respect to the composition of the biota and to process rates. Here the relative significance of chemoautotrophic sulphide oxidation was highly variable. During summer the surface microbial communities of this sediment were dominated by phototrophs and the colourless sulphur bacteria constituted a less important component.
\end{abstract}

KEY WORDS: Microbial mats Chemoautotrophic production Colourless sulphur bacteria - Oxicanoxic interphase

\section{INTRODUCTION}

Dense layers of colourless sulphur bacteria may form conspicuous white patches ranging in size from a few millimetres to several metres diameter on the surface of marine sediments. The phenomenon is known from many different benthic habitats including deep sea and shallow hydrothermal vents (Powell et al. 1983, Karl 1987, Jannasch et al. 1989), below productive upwelling areas (Fossing et al. 1995, Gallardo et al. 1995), and permanently or occasionally in various productive shallow water areas (Fenchel 1969, Ankar \& Jansson 1973, Jørgensen 1977b, Juniper \& Brinkhurst 1986). These communities are dominated by large bacteria which can be recognised morphologically and include filamentous and colonial forms such as Beggiatoa and Thioploca as well as unicellular forms such as Thiobacillus, Thiovulum, Thiospira and Macromonas (e.g. La Rivière \& Schmidt

\footnotetext{
•E-mail: marilab@inet.uni-c.dk

- Present address: School of Biology A08, University of Sydney, Syndey, New South Wales 2006, Australia
}

1992); in reflected light these bacteria appear white due to inclusions of elemental sulphur. The organisms use sulphide as substrate and oxidise it to elemental sulphur or to sulphate; excepting the case of geothermal vents, the sulphide derives from dissimilatory sulphate reduction in the underlying anaerobic sediment.

In sediments with a 'suboxic zone' (that is, a microor anaerobic zone without detectable free sulphide), microbial sulphide oxidation is not confined to a narrow zone (Jørgensen 1977a). This may also apply to geothermal vents where advection creates centimetrethick zones in which sulphide and oxygen coexist (Jannasch et al. 1989, P. Dando pers comm.). However, when low oxygen and low sulphide concentrations coexist within the chemocline and when the vertical fluxes of these compounds depend only on molecular diffusion, the sulphur bacteria will form distinct 200 to $600 \mu \mathrm{m}$ thick layers and the metabolic activity of the bacteria maintains extremely steep gradients of sulphide and oxygen (Jørgensen \& Revsbech 1983, Nelson et al. 1986b). If the zone of overlap between sulphide and oxygen is situated at (or above) the sedi- 
ment surface, the bacterial mats become visible. In sediments with photosynthetic activity the layer of white sulphur bacteria (together with the associated biota) performs diurnal vertical migrations and it appears on the surface only during darkness; in the light it is found beneath a layer of phototrophic microorganisms (e.g. Fenchel 1969, Garcia-Pichel et al. 1994, Fenchel \& Bernard 1995).

Many aspects of these bacteria including their diversity, metabolism, growth yield, and chemosensory motile behaviour have previously been studied in detail (e.g. Jørgensen \& Revsbech 1983, Møller et al. 1985, Nelson et al. 1986a, b, Kuenen 1989, Nelson 1989, La Rivière \& Schmidt 1992, Fenchel 1994). With respect to the role of colourless sulphur bacteria for phagotrophic food chains and the composition of the associated biota, it is mainly exotic habitats (such as deep sea hydrothermal vents) which have drawn attention. In spite of some earlier work (Fauré-Fremiet 1951, Fenchel 1969) shallow water mats of colourless bacteria have mainly been considered as a sign of environmental deterioration and ecological studies have been very limited. Notwithstanding that anthropogenic eutrophication may lead to an expansion of areas covered by such mats, these do represent natural, complex and diverse communities.

The present paper describes the role of mats of colourless sulphur bacteria in the carbon cycling of 2 types of sediments, interactions with other microbial components and the trophic role of chemoautotrophic production. A following paper (Bernard \& Fenchel 1995) will describe the biota and successional patterns.

\section{MATERIAL AND METHODS}

Sediment cores (diameter $5 \mathrm{~cm}$ ) were collected by SCUBA diving in the outer basin of the North Harbour in Helsingør, Denmark, during the period November 1994 to April 1995. The sediment consists of poorly sorted fine sand with a high content of organic material $(-15 \%$ of dry wt) mainly in the form of debris of macroalgae and seagrass tissue and with a porosity of about $80 \%$. Large patches of white sulphur bacteria dominated by large Beggiatoa filaments and often measuring several metres in diameter are evident throughout the year (Fig. 1); between these white patches the layer of sulphur bacteria is covered by a layer of cyanobacteria and/or diatoms. In periods with strong wind exposure the upper few millimetres of the sediment become fully oxidized and the sulphur bacteria are not visible on the surface; conversely, during long calm periods the water column immediately above the sediment may become anoxic and the water is then cloudy from suspended sulphur bacteria.
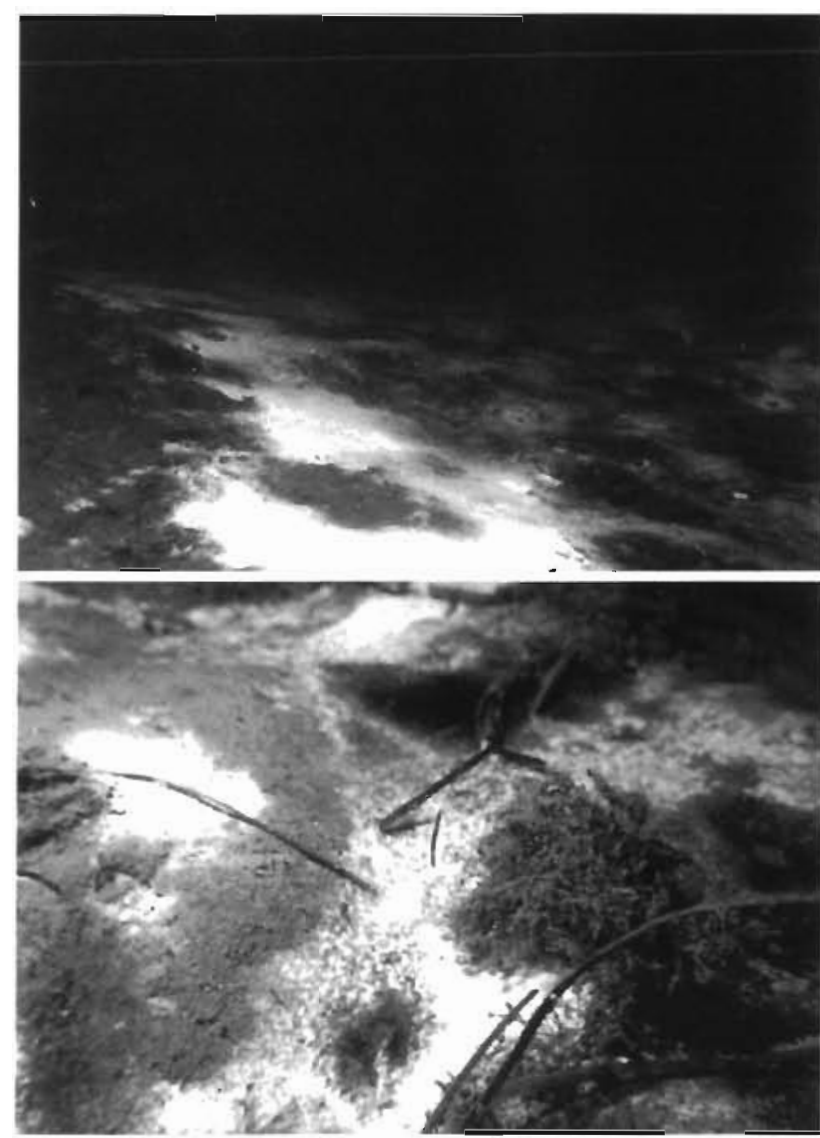

Fig. 1 Beggiatoa mats at $6.5 \mathrm{~m}$ depth in North Harbour, Helsingor, Denmark. In the close up (below) the egelgrass leaves are about $0.5 \mathrm{~cm}$ wide. Photograph by I. Aagaard

Samples were also collected in the innermost part of Nivå Bay about $15 \mathrm{~km}$ south of Helsingør at water depths from 0.1 to $0.5 \mathrm{~m}$. The sediment consists of wellsorted sand with a median grain size of about $250 \mu \mathrm{m}$; organic contents were not measured. From autumn to spring patches of white sulphur bacteria (usually smaller than $20 \mathrm{~cm}$ ) are evident except immediately after windy periods when the surface layers are oxidised to a depth of several millimetres to centimetres. The composition of the sulphur bacteria varies according to the age of the patch, the younger ones being dominated by Thiospira and/or Thiovulum and more mature patches by Beggiatoa (see Bernard \& Fenchel 1995 for details). During summer, white sulphur bacteria are usually only visible on the surface during night and early morning; in the light they migrate down into microbial mats dominated by diatoms, cyanobacteria and purple sulphur bacteria. The Nivå Bay locality is described in more detail in Fenchel $(1969,1993)$ Samples were collected by hand by pressing plexiglass tubes (inner diameter 4.2 or $7 \mathrm{~cm}$ ) into the sediment. Samples were collected from April to July 1994 and in autumn and winter 1994/95. Finally, a few cores were 
collected in shallow water in the innermost part of the Helsingør North Harbour. In the laboratory the collected cores were kept at room temperature $\left(20^{\circ} \mathrm{C}\right)$ in $\operatorname{dim}$ daylight and the overlying water was continuously bubbled with air.

Oxygen, sulphide and $\mathrm{pH}$ profiles were measured in the laboratory at $\sim 20^{\circ} \mathrm{C}$ on the day of sampling or on the following day. As shown below, the $\mathrm{O}_{2}^{-}$and $\mathrm{S}^{2-}$ gradients were reversibly affected by changes in light intensity and in the intensity of bubbling; otherwise the gradients remained unchanged for at least $4 \mathrm{~d}$ in the laboratory. We used $\mathrm{O}_{2}$-microelectrodes constructed according to Revsbech \& Jørgensen (1986) and a picoammeter and a polarisation voltage of $-0.75 \mathrm{~V}$. During measurements the electrodes were calibrated at the surface of the bubbled water [ $100 \%$ atmospheric saturation (atm. sat.)] and about $1 \mathrm{~mm}$ below the sediment surface $(0 \%)$. For $\mathrm{pH}$ measurements we used a 'needle electrode' (MI-407. Microelectrodes, Inc, Londonderry, NH, USA) together with a pH meter (Radiometer, Copenhagen). Sulphide electrodes were made by etching the end of thin silver wire with nitric acid to a diameter of 50 to $100 \mu \mathrm{m}$. The wire was then mounted in glass capillaries with araldite and the exposed silver tip was coated electrolytically with $\mathrm{Ag}_{2} \mathrm{~S}$. Potentials were read against a calomel electrode using a pH meter. The electrodes were initially calibrated in sulphide solutions and total sulphide was later calculated from the measured potential and corresponding measurements of $\mathrm{pH}$. Total sulphide $\left(\mathrm{S}^{2-}+\right.$ $\mathrm{HS}^{-}+\mathrm{H}_{2} \mathrm{~S}$ ) is referred to as 'sulphide' or $\mathrm{S}^{2-}$ in the following. Oxygen will be expressed as $\mathrm{P}_{2}(\%$ atmospheric pressure $; 100 \%$ atm. sat. $=21.2 \mathrm{kPa}$ ), but for flux estimates the values were converted to molar concentrations on the basis of salinity and temperature. All other concentrations are expressed as mol $\mathrm{l}^{-1}$.

The profiles were measured with the electrodes mounted in a micromanipulator and measurements were taken at depth intervals of 50 or $100 \mu \mathrm{m}$. Zero depth was determined as the point where the electrode tips just touched the surface of the sediment or of the bacterial mat as observed with a dissection microscope. Typical results are shown in Figs. 2 ( $600 \mu \mathrm{m}$ thick Beggiatod mat) and $3(-200 \mu$ thick Thiovulum film). Flux was estimated as the slope of the linear part of the profile, assuming that linearity reflects that the substance is conservative in this region and that diffu- sion coefficients are constant with depth. Flux can then be calculated from Fick's law as $J=D \frac{\mathrm{d} C}{\mathrm{~d} z}$ where $D$ represents diffusion coefficients (taken from Cussler 1989), $C$ is concentration and $z$ is depth. Since the slope of $\mathrm{O}_{2}$ gradients did not change when passing from the water and into the mat (Fig. 2) and since porosity of the bacterial mat is at least $\sim 90 \%$ isee Bernard \& Fenchel 1995), we did not correct for porosity in the superficial $<1 \mathrm{~mm}$ top of the sediment. The effect of the vertically descending electrode on the diffusive boundary layer above the sediment (and hence

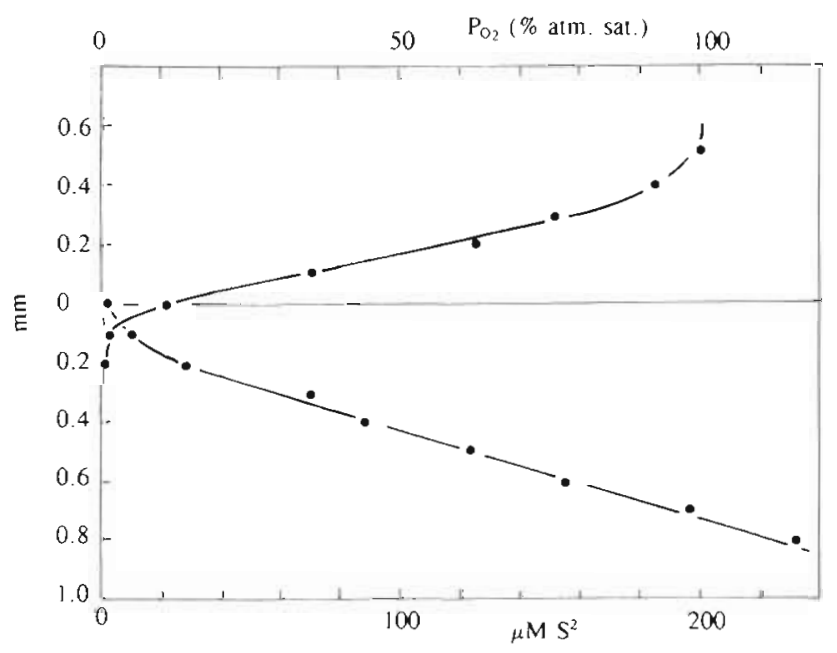

Fig. 3. $\mathrm{O}_{2}^{-}$and $\mathrm{S}^{2-}$ profiles in a sediment surface (Nivä Bay, Denmark) with a $200 \mu \mathrm{m}$ thick Thiovulum film 


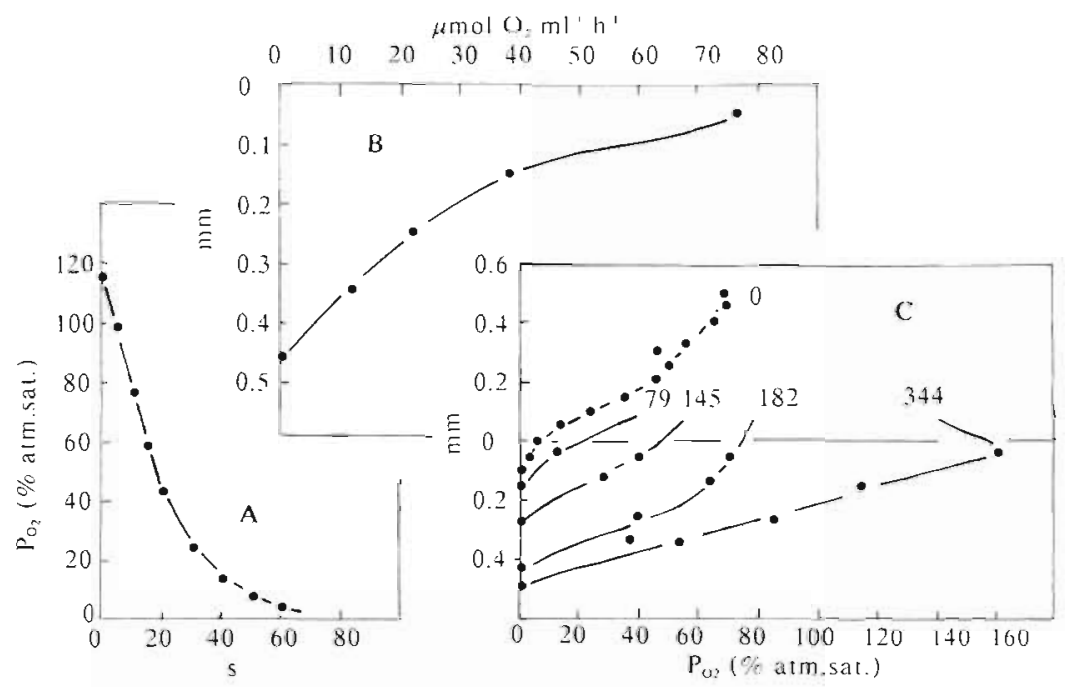

Fig. 4. Oxygenic photosynthesis in a Beggiatoa mat. (A) Decrease in $\mathrm{P}_{2}$ at a depth of $200 \mu \mathrm{m}$ after light had been turned off (initial surface illumination: $344 \mu \mathrm{E} \mathrm{m}^{-2} \mathrm{~s}^{-1}$ ); the initial slope is the photosynthetic rate at this depth. (B) Photosynthetic rate as function of depth. (C) Steady state $\mathrm{O}_{2}$ profiles at different light intensities (expressed as $\mu \mathrm{E} \mathrm{m}^{-2}$ $\mathrm{s}^{-1}$ ). (D) Photosynthetic rate per unit area as a function of surface illumination

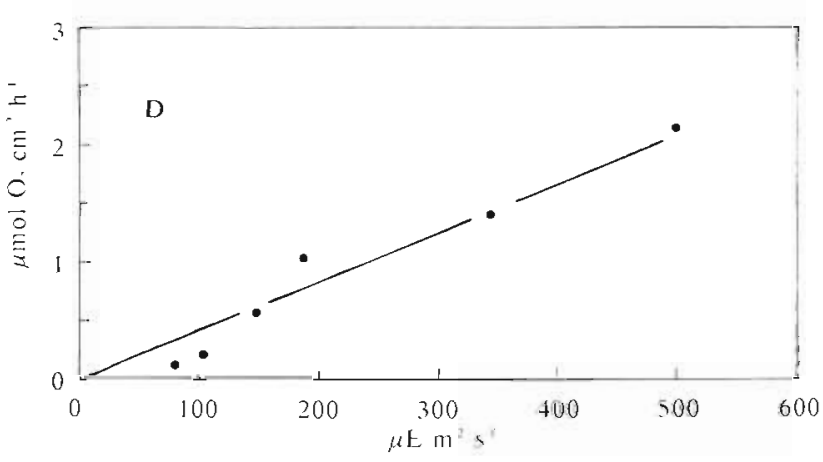

on the $\mathrm{O}_{2}$ profile) demonstrated by Glud et al. (1994) was ignored for technical reasons (it was not possible to introduce the electrodes from beneath). For crude estimates of $\mathrm{CO}_{2}, \mathrm{CH}_{4}$ and $\mathrm{SO}_{4}{ }^{2-}$ fluxes (see below) we did compensate for porosity following the empirical equation of Rasmussen \& Jørgensen (1992). Photosynthetic rates were measured following the technique of Revsbech et al. (1981). Briefly, $\mathrm{O}_{2}$ electrodes were placed at a given depth in a core which was exposed with a known surface light intensity for a sufficiently long period ( $15 \mathrm{~min})$ to reach a steady state $\mathrm{O}_{2}$ tension. The light was then turned off and the initial linear decrease in $\mathrm{O}_{2}$ tension was then a measure of photosynthetic rate at the position of the electrode tip. Repeating this for several depths and integrating the resulting curve yields an estimate of the photosynthetic rate per unit area (Fig. 4)

To measure dissolved $\mathrm{CO}_{2}, \mathrm{CH}_{4}$ and $\mathrm{SO}_{4}{ }^{2-}, 1 \mathrm{ml}$ interstitial water was drawn from the side of cores through $1 \mathrm{~mm}$ holes filled with silicone rubber at 0.5 or $1 \mathrm{~cm}$ intervals. Sulphate was determined on filtered samples by turbidometry following precipitation with $\mathrm{BaCl}_{2}$ (American Public Health Association 1975). For $\mathrm{CH}_{4}$ and $\mathrm{CO}_{2}$ measurements, samples were placed in $15 \mathrm{ml}$ serum bottles with rubber stoppers and alu- minum seals and $1 \mathrm{ml} 0.01 \mathrm{~N} \mathrm{HCl}$ was added through a syringe needle. After vigorous shaking, 100 ll headspace samples were injected in a gas chromatograph (Chrompack CP9000, Middelburg, The Netherlands) with a Porapak $\mathrm{Q}$ column with $\mathrm{N}_{2}$ as carrier and with a TCD or a FID detector for measuring $\mathrm{CO}_{2}$ and $\mathrm{CH}_{4}$, respectively. For measuring methanogenesis $1 \mathrm{ml}$ sediment from different depths and $1 \mathrm{ml} \mathrm{O}_{2}$-free seawater were placed in $15 \mathrm{ml}$ stoppered serum bottles and the headspace was flushed with $\mathrm{O}_{2}$-free $\mathrm{N}_{2}$. The bottles were placed on a shaking table and after $1 \mathrm{~h}$ the headspace was again flushed with $\mathrm{N}_{2}$ in order to remove residual $\mathrm{CH}_{4}$. Thereafter $100 \mu \mathrm{l}$ gas samples were taken at $1 \mathrm{~h}$ intervals and analysed for $\mathrm{CH}_{4}$ and the linear increase with time was used as a measure of methanogenesis

\section{RESULTS AND DISCUSSION}

\section{Spatial and temporal heterogeneity}

\section{Effect of temperature}

Since measurements were otherwise all carried out at $-20^{\circ} \mathrm{C}$, we measured $\mathrm{O}_{2}$ profiles on 3 cores collected simultaneously in the harbour locality and kept for $20 \mathrm{~h}$ at 4,8 and $20^{\circ} \mathrm{C}$, respectively. This yielded a $Q_{10}$ of about 1.8 for this range. This allowed for a crude conversion of measured rates to temperatures measured in the field.

\section{Effect of turbulence, advection and $\mathrm{P}_{\mathrm{O}_{2}}$ of the overlying water}

As previously demonstrated by Jørgensen \& Des Marais (1990), O $\mathrm{O}_{2}$ uptake of sediments with a high respiration rate is influenced by advective and turbulent 


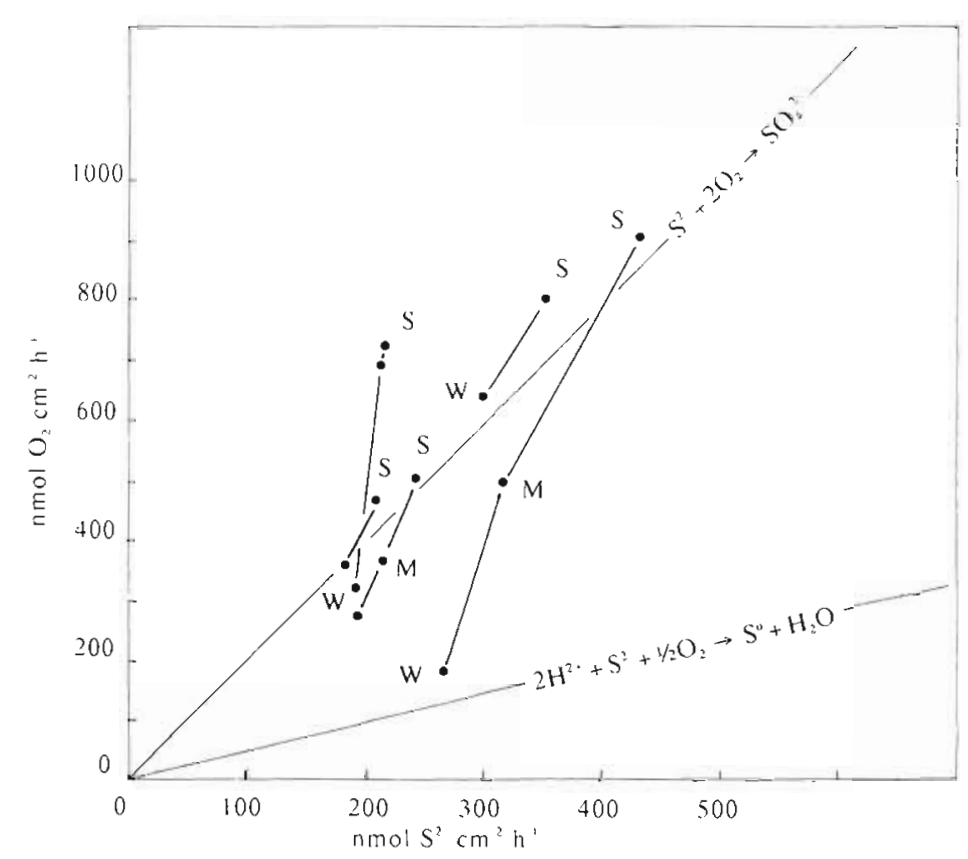

Fig. 5. Fluxes of $\mathrm{S}^{2-}$ and $\mathrm{O}_{2}$ of Beggiatoa mats as a function of turbulence [intensity of bubbling: (S) strong. (M) medium, (W) weak] in the overlying water column

water movement since this affects the thickness of the diffusive boundary layer, which again limits the flux of $\mathrm{O}_{2}$ from the water. This effect was studied in cores from the harbour by changing the (unquantified) intensity of air bubbling in the overlying water (Fig. 5). When the bubbling was decreased to a low intensity, the oxic-anoxic boundary layer migrated upwards by up to $400 \mu \mathrm{m}$ (sometimes ending 200 to $300 \mu \mathrm{m}$ above the surface) within minutes. The Beggiatoa filaments responded by extending up into the water so that the mat achieved a woolly appearance. At the same time the $\mathrm{O}_{2}$ flux decreased. It is apparent from Fig. 5 that the $S^{2-}$ flux did not decrease accordingly so that the $\mathrm{O}_{2}$ flux $/ \mathrm{S}^{2-}$ flux ratio decreased with decreasing $\mathrm{O}_{2}$-availability. The explanation is probably that the $\mathrm{O}_{2}$-limited bacteria preferably oxidise $\mathrm{S}^{2-}$ incompletely to $\mathrm{S}^{0}$ and so store elemental sulphur. In mats dominated by free-swimming sulphur bacteria (such as Thiovulum) the cells are capable of following the $\mathrm{O}_{2}$ gradients up into the water column (Fenchel 1994). A similar change in the ratio of $\mathrm{S}^{2-}$ and $\mathrm{O}_{2}$ with changing water flow is therefore not expected, but this was not investigated.

For all measurements shown in Fig. 8 a vigorous bubbling was used, but since this could not be standardised very well the effect explains some of the variation in $\mathrm{O}_{2}$ flux estimates. The effect may also have contributed indirectly to the variance of $\mathrm{O}_{2}$ uptake, especially evident in the case of the Niva
Bay samples (see Fig 8). When samples were collected, spots with conspicuous covering of white sulphur bacteria were chosen. Whether the sulphur bacteria occur at the surface, however, depends not only on the intensity of sulphide flux from the underlying sediment, but also on the turbulence of the overlying water; collection on very calm days could therefore result in samples with a relatively low $\mathrm{O}_{2}$ and $\mathrm{S}^{2-}$ uptake rates as compared to samples from more windy periods.

\section{Spatial heterogeneity}

Spatial heterogeneity was especially evident in Nivá Bay. Fig. 6 shows the $\mathrm{O}_{2}$ isopleths along a $5 \mathrm{~mm}$ transect including a stretch of about $2 \mathrm{~mm}$ long where colourless sulphur bacteria were evident on or slightly above the surface. It also shows that the $\mathrm{O}_{2}$ flux along the transect varied by a factor of almost 3 . The reason for this was probably the heterogenous distribution of decomposing organic material in the sediment (there were no signs of larger burrowing animals in the immediate vicinity of the transect). This clearly shows that fluxes of $\mathrm{O}_{2}$ and of $\mathrm{S}^{2-}$ measured at one point cannot be taken as an average value for a finite area of the sediment

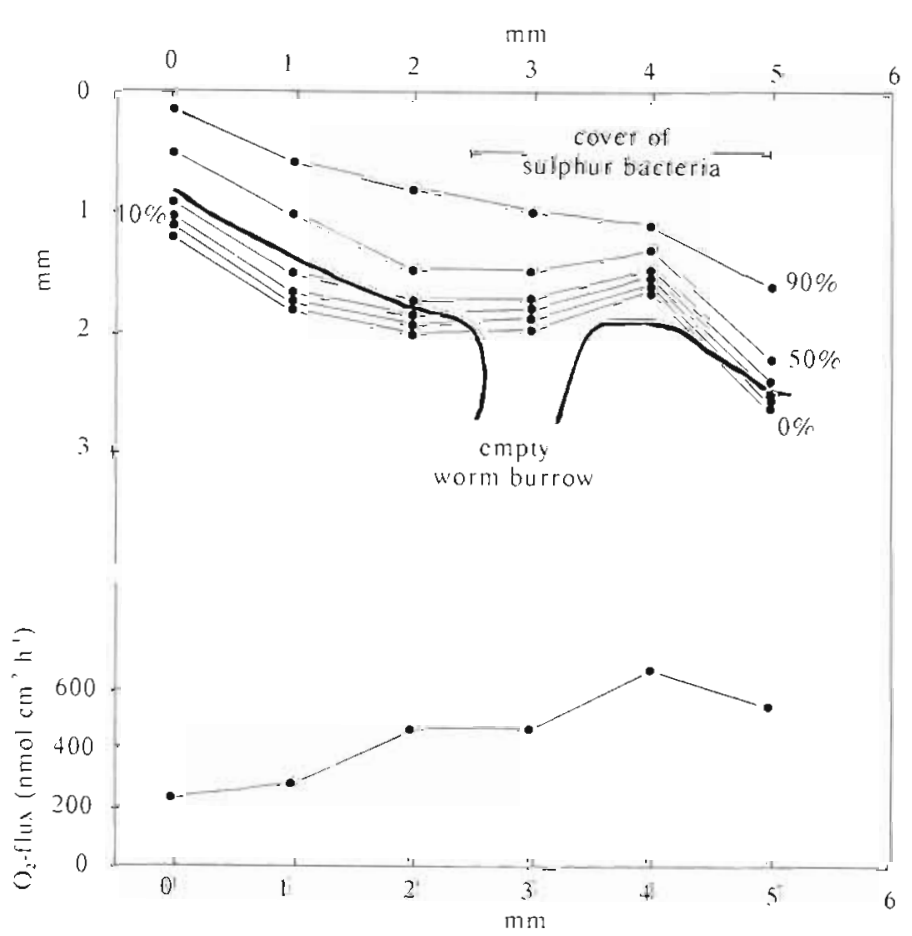

Fig. 6. $\mathrm{O}_{2}$ isopleths and $\mathrm{O}_{2}$ flux along a $5 \mathrm{~mm}$ long transect of the surface of a sediment (Nivå Bay) 
surface. In addition, and as previously observed by Jorgensen \& Des Marais (1990), the $\mathrm{O}_{2}$ isopleths tend to trace the irregular topography of the sediment surface; this results in a systematic underestimation of the sediment $\mathrm{O}_{2}$ uptake on an areal basis if it is calculated from $\mathrm{O}_{2}$ profiles

An additional cause of heterogeneity of the Niva Bay samples is that they derive from patches which undergo successional changes. Occasional exposure to waves and currents results in sediment transport and erosion; the surface layers of the sediment are then oxidised and at the same time fresh organic material is buried. In following calm periods sediment patches with a higher amount of buried organic material and thus a more intense sulphate reduction develop a cover of colourless sulphur bacteria; these mat communities undergo characteristic successional stages over a period of 1 to $2 \mathrm{wk}$. This is described in more detail in Bernard \& Fenchel (1995); see also Fenchel (1993).

\section{Major microbial processes and the role of chemoautotrophic production}

Fig. 7 shows an example of concentration profiles of $\mathrm{S}^{2-}, \mathrm{SO}_{4}{ }^{2-}, \mathrm{CO}_{2}$ and $\mathrm{CH}_{4}$ as well as a profile of the rate of methanogenesis to a depth of $14 \mathrm{~cm}$ in the $6.5 \mathrm{~m}$ harbour site. The concentration gradients can only be used for a very crude estimate of process rates due to vertical heterogeneity and because over distances of several centimetres the gradients may not represent a steady state situation. However, 3 measured gradients of $\mathrm{CO}_{2}$ in the upper centimetres of the sediment corresponded to a flux of 600 to $800 \mathrm{nmol} \mathrm{CO} \mathrm{Cm}^{-2} \mathrm{~h}^{-1}$, which is consistent with estimates of sulphate reduction rates of 300 to $400 \mathrm{nmol} \mathrm{cm} \mathrm{cm}^{-2} \mathrm{~h}^{-1}$ (cf. Fig. 8), provided that sulphate reduction is the dominating terminal mineralisation process. There was a small concentration peak of $\mathrm{CH}_{4}$ and of the rate of methanogenesis at 3 to $6 \mathrm{~cm}$ depth, but high concentrations and production rates were evident only when $\mathrm{SO}_{4}{ }^{2-}$ was depleted at a depth of 8 to $10 \mathrm{~cm}$. Below this depth, gas pockets were observed in the sediment. Integrated $\mathrm{CH}_{4}$-production (down to $14 \mathrm{~cm}$ ) was about $25 \mathrm{nmol}$ $\mathrm{cm}^{-2} \mathrm{~h}^{-1}$ corresponding to $<10 \%$ of the total anaerobic carbon mineralisation. The concave-upward shape of the $\mathrm{CH}_{4}$ around $8 \mathrm{~cm}$ suggests that the bulk of the methane produced is oxidised anaerobically through sulphate reduction (e.g. Iversen \& Blackburn 1981, Iversen \& Jørgensen 1985) although it is also possible that some methane escapes through ebullition.

Fig. $8 \mathrm{~A}$ shows corresponding values of $\mathrm{O}_{2}$ and $\mathrm{S}^{2-}$ fluxes to the Beggiatoa mat. The values are consistent with those previously found for a similar sediment (Jør-

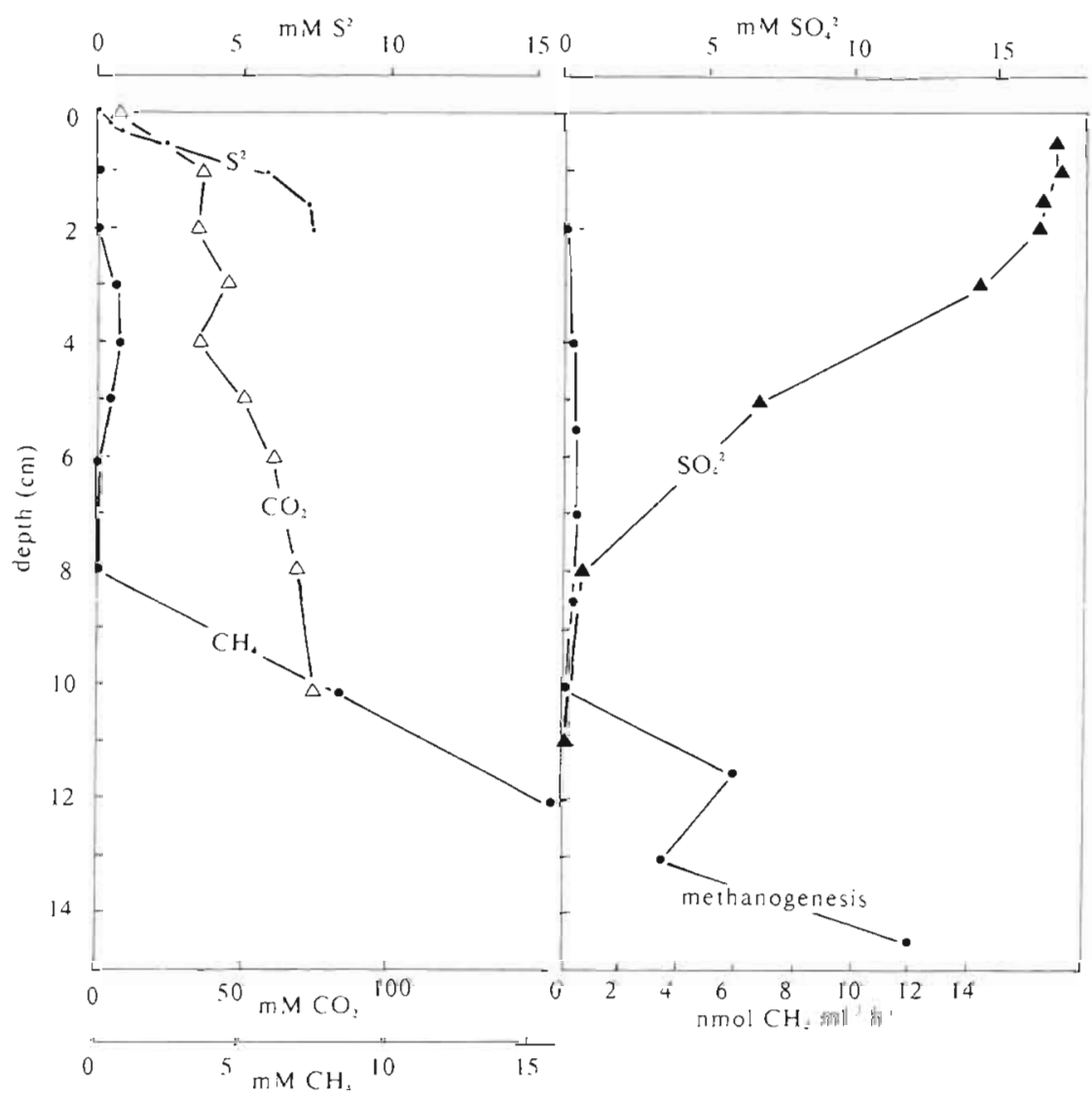

Fig. 7 Profiles of $\mathrm{CO}_{2}, \mathrm{~S}^{2-}, \mathrm{CH}_{4}, \mathrm{SO}_{4}^{2}$ and of the rate of methanogenesis in the sediment beneath a Beggiatoa mat. The sulphate profile derives from a separate sediment core 


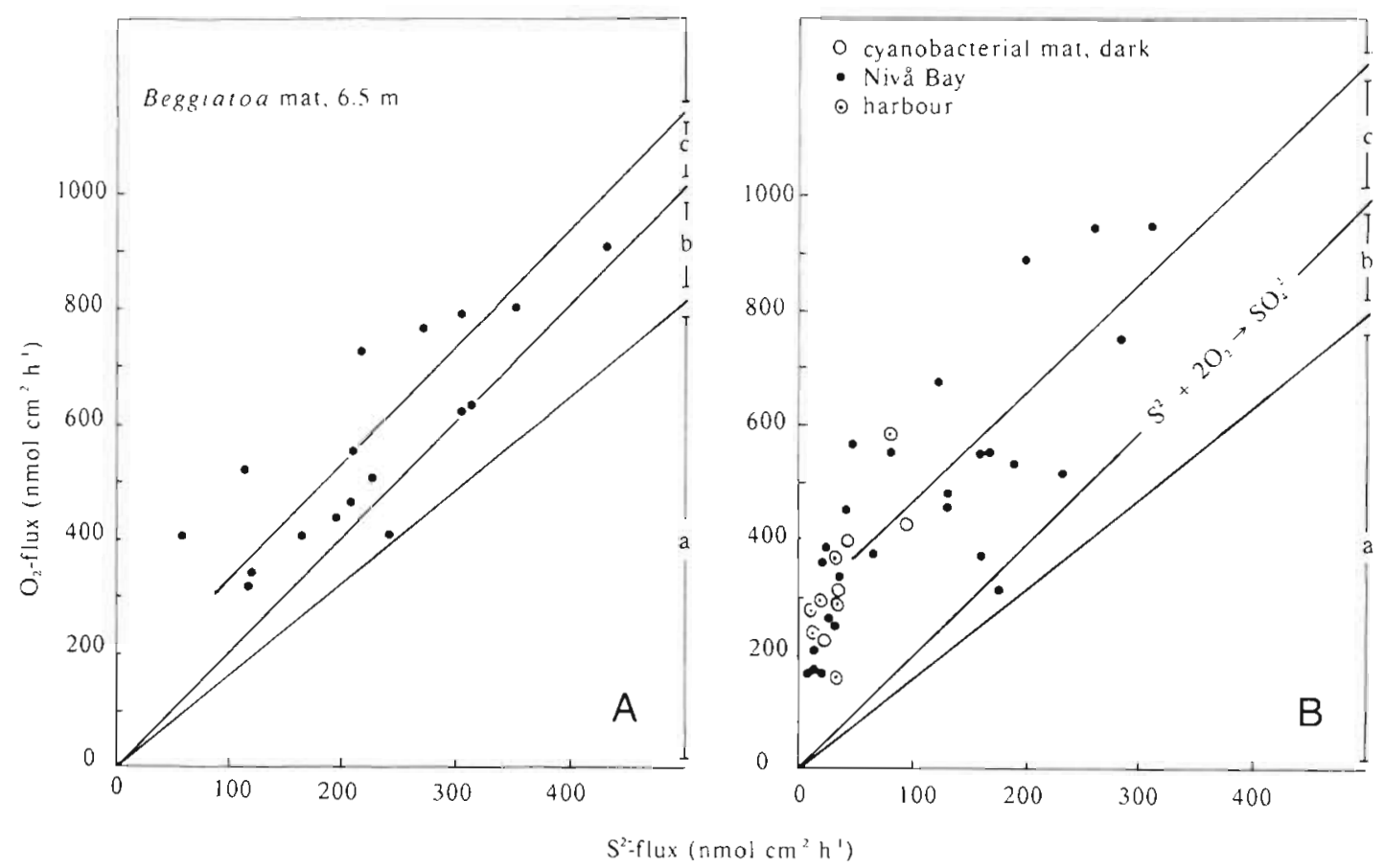

Fig. 8. Corresponding fluxes of $\mathrm{S}^{2-}$ and $\mathrm{O}_{2}(\mathrm{~A})$ of the Beggiatoa mat from the North Harbour at $6.5 \mathrm{~m}$ and (B) from patches with various types of colourless sulphur bacterla or cyanobacterial mats (in the dark) from Niva Bay and from the shallow site in the harbour. For further explanation see text

gensen 1977b) and for other active biofilms (Kühl \& Jørgensen 1992). With the assumption that the mat is in a steady state (no net change in biomass) then the flux estimates can be used to estimate the fraction of the $\mathrm{O}_{2}$ uptake due to $\mathrm{S}^{2-}$ oxidation, the chemoautotrophic production by sulphur bacteria and the fraction of the $\mathrm{O}_{2}$ uptake which is not directly associated with the $\mathrm{S}$ cycle. The slope of $\mathrm{O}_{2}$ versus $\mathrm{S}^{2-}$ flux (2:1) suggests that complete oxidation to $\mathrm{SO}_{4}{ }^{2-}$ took place. In Fig. $8, a+b$ corresponds to $\mathrm{S}^{2-}+2 \mathrm{O}_{2} \rightarrow \mathrm{SO}_{4}^{2-}$. However, since the sulphur bacteria grow by assimilatory reduction of $\mathrm{CO}_{2}$, some of the consumed sulphide is used as an electron donor for $\mathrm{C}$ reduction rather than for $\mathrm{O}_{2}$ reduction (Nelson et al. 1986a). The molar yield of sulphide-oxidising bacteria (with $\mathrm{SO}_{4}{ }^{2-}$ as the principal end product) has been measured to be within the range of 6 to $10 \mathrm{~g}$ dry wt organic material $\mathrm{mol}^{-1} \mathrm{~S}^{2-}$ oxidised (Kuenen 1989); we here use the value of $0.4 \mathrm{~mol}$ $\mathrm{C} \mathrm{mol}^{-1} \mathrm{~S}^{2-}$ found by Nelson et al. (1986b) in a pure culture of Beggiatod; this corresponds to $b$ in Fig. 8. Thus $a+b+c$ corresponds to the total $\mathrm{O}_{2}$ uptake of the sediment, a represents the part of the $\mathrm{O}_{2}$ uptake directly used for $\mathrm{S}^{2-}$ oxidation, $b$ is the production of sulphur bacteria (in $\mathrm{C}$ equivalents or in $\mathrm{O}_{2}$ equivalents when this biomass is eventually mineralised aerobically). Finally, $c$ represents the part of the sediment respiration which is not directly associated with the sulphur cycle (e.g. respiration of phototrophs in the dark, respi- ration of various heterotrophic aerobes not consuming or degrading sulphur bacteria, and the respiration of nitrifiers and methylotrophic bacteria). Thus for a typical sulphide flux, about $70 \%$ of the sediment respiration (= input of organic $\mathrm{C}$ to the system - burial of fossil organic $\mathrm{C}$ and of pyrite) is accounted for by the oxidation of $\mathrm{S}^{2-}$ to $\mathrm{SO}_{4}{ }^{2-}$, about $15 \%$ by the mineralisation of chemoautotrophic production (through food chains or heterotrophic bacteria) and about $15 \%$ by other aerobic processes

The Beggiatoa mat in the harbour contained a substantial amount of filamentous cyanobacteria and sometimes substantial numbers of diatoms and green euglenoids, and when exposed to full daylight in the laboratory, the sulphur bacteria migrated beneath the phototrophs, leaving a brownish-green surface layer. The rate of photosynthesis as a function of light intensity is shown in Fig. 4. Direct measurements showed that $<5 \%$ of incident surface light penetrates to $6.5 \mathrm{~m}$ depth so that the photosynthetic potential exceeds realised in situ values. Even under favourable conditions during summer, the phototrophs are not capable of covering the $\mathrm{O}_{2}$ and organic $\mathrm{C}$ demands of the sediment and the main carbon supply must derive from accumulated organic debris (mainly tissue of eelgrass and macroalgae).

Fig. 9 summarises the flow of materials and energy in the upper $14 \mathrm{~cm}$ of the harbour site sediment and its 


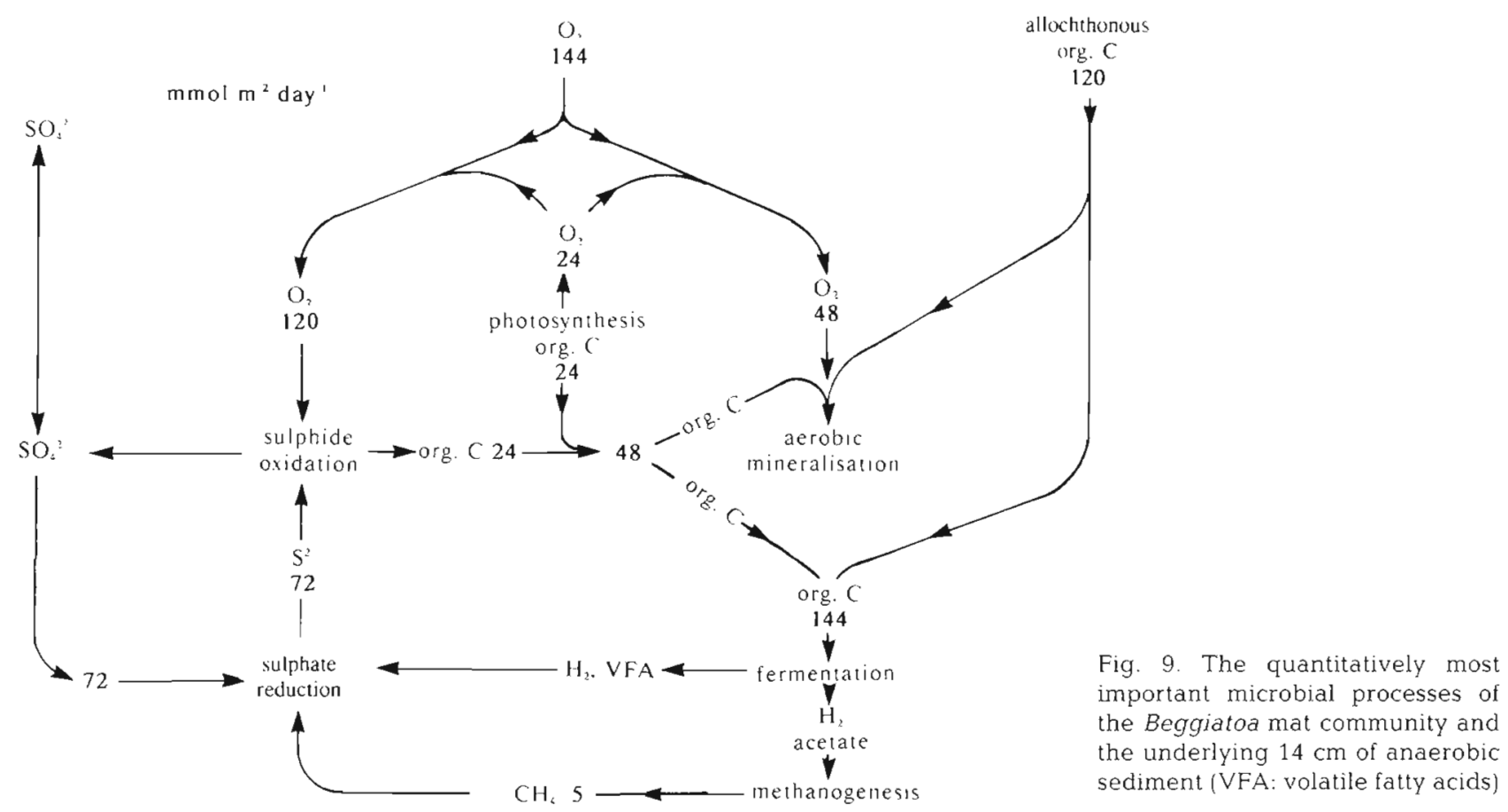

microbial mat. The figures are not to be considered as an average over time or space, but as representations of an example based on a $\mathrm{S}^{2-}$ flux of $300 \mathrm{nmol} \mathrm{cm}^{-2} \mathrm{~h}^{-1}$ and a dark $\mathrm{O}_{2}$ consumption of $700 \mathrm{nmol} \mathrm{cm}^{-2} \mathrm{~h}^{-1}$. The photosynthetic rate is a crude estimate based on a typical photon flux at $6.5 \mathrm{~m}$ depth during daytime in spring and an extrapolation of the data shown in Fig. 4D.

There are 2 more serious reservations with respect to Fig. 9. The cores from the harbour never showed visible signs of phototrophic (purple or green) sulphur bacteria, not even if the sides of cores were exposed to light for several days. It is known, however, that many cyanobacteria are both tolerant to sulphide and capable of anoxygenic photosynthesis with $S^{2-}$ as an electron donor (Cohen et al. 1986). In addition, filamentous cyanobacteria were observed to congregate in the sulphidic zone on the illuminated side of cores. It is therefore possible that some phototrophic (anoxic) sulphide oxidation took place in the light.

It is also possible that some sulphide oxidation took place with nitrate rather than oxygen as the electron acceptor according to Fig. 10; it has been shown that at least some colourless sulphur bacteria may be denitrifiers (Kuenen 1989). The nitrate would derive from nitrification in the lower part of the oxic zone, based on $\mathrm{NH}_{4}{ }^{+}$diffusing upwards from the anoxic zone, and some of the formed $\mathrm{NO}_{3}{ }^{-}$could diffuse downwards and serve for sulphide oxidation via denitrification. If this mechanism were important, then the overall stoichiometry of sulphide oxidation by $\mathrm{O}_{2}$ would be different than suggested in Fig. 9. This is because in nitrification
$\mathrm{NH}_{4}{ }^{+}$is oxidised to $\mathrm{NO}_{3}{ }^{-}$In denitrification, however, $\mathrm{NO}_{3}{ }^{-}$is reduced only to $\mathrm{N}_{2}$. The oxidation of 1 unit of $\mathrm{S}^{2-}$ would therefore require 3.2 rather than 2 units of $\mathrm{O}_{2}$ if it takes place via nitrification-denitrification. Although nitrification-denitrification was not studied, it is possible to set an upper bound for its quantitative role. Assuming a $\mathrm{C}: \mathrm{N}$ ratio of 6 for the anaerobically mineralised organic material, an upwards $\mathrm{NH}_{4}{ }^{+}$flux of about $100 \mathrm{nmol} \mathrm{cm}^{-2} \mathrm{~h}^{-1}$ is predicted. Complete nitrification would then require $17 \%$ of the total $\mathrm{O}_{2}$ consumption. It is, however, known that denitrification is incomplete in sediments with a reducing zone close to the surface (Vanderborght \& Billen 1975). Furthermore, it is unlikely that all the produced $\mathrm{NO}_{3}{ }^{-}$would become available for denitrification and it is therefore unlikely that the pathway described in Fig. 10 is quantitatively important for sulphide oxidation. The sul-

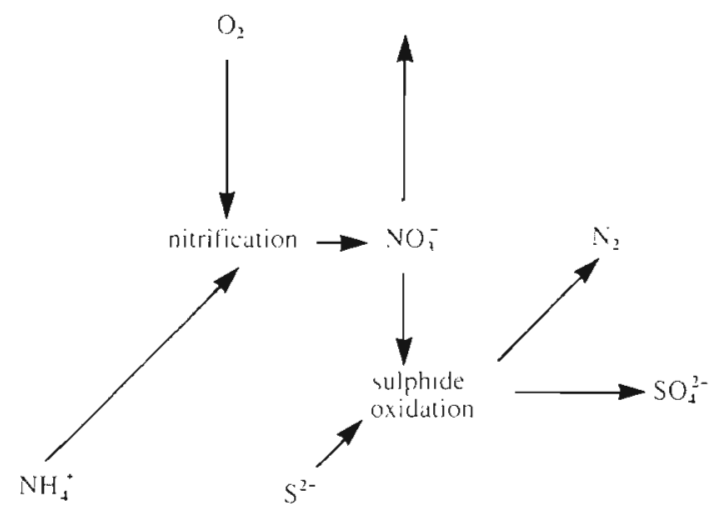

Fig. 10. Nitrification-denitnfication as a possible intermediate in the overall oxidation of $\mathrm{S}^{2-}$ by $\mathrm{O}_{2}$ to $\mathrm{SO}_{4}{ }^{2}$ 
phide profiles in Beggiatoa mats suggest that $\mathrm{S}^{2-}$ oxidation took place within the entire $(500$ to $600 \mu \mathrm{m}$ thick) mat although $\mathrm{O}_{2}$ could only be detected in the upper 150 to $200 \mu \mathrm{m}$. Denitrification could be a contributing explanation for this. Thus Fossing et al. (1995) found that nitrate is a major electron acceptor for Thioploca mats of the upwelling areas off the coast of Chile, and that the bacteria store $\mathrm{NO}_{3}{ }^{-}$in vacuoles and transport it down into the sulphidic zone by vertical migration. This mechanism, however, requires high $\mathrm{NO}_{3}$. concentrations in the overlying water, a condition which does not apply in the present case. Also, the $K_{\mathrm{s}}$ for $\mathrm{O}_{2}$-uptake of sulphur bacteria is very low ( $0.5 \%$ atm. sat. according to Kuenen 1989). This is at or below the detection limit of the $\mathrm{O}_{2}$-electrodes, so very low and undetectable amounts of $\mathrm{O}_{2}$, although still sufficient to sustain some aerobic activity, may have been present slightly deeper than indicated in Fig. 2. The individual Beggiatoa filaments are in constant motion and are therefore subject to a varying $\mathrm{PO}_{2}$.

Fig. $8 \mathrm{~B}$ shows corresponding values of $\mathrm{S}^{2-}$ and $\mathrm{O}_{2}$ fluxes of Nivå Bay samples (including a few summer samples with cyanobacterial mats which were measured in the dark) and of samples from the shallow site in the harbour. Most of these samples were dominated by free-swimming colourless sulphur bacteria (mainly Thiovulum); these form thinner films $(-200 \mu \mathrm{m})$ which avoid complete anoxia (Fig. 3; see also Fenchel 1994 Bernard \& Fenchel 1995). These samples showed a much larger variation in terms of $\mathrm{S}^{2-}$ flux and in terms of the ratio between $\mathrm{S}^{2-}$ and $\mathrm{O}_{2}$ flux, reflecting the transient nature of the patches. In these shallow water samples phototrophic $\mathrm{S}^{2-}$ oxidation plays a substantial role from spring to autumn. As seen in Fig. 8, chemotrophic sulphide oxidation often accounted for $<50 \%$ of the total respiration and chemoautotrophic production for only 10 to $30 \%$ of the $\mathrm{C}$ demand of aerobic heterotrophs.

Acknowledgements. The study was supported by grants from the Danısh Natural Science Research Council (0088-1) and from the European Union (MAST Programme, 93-0058). We are grateful to $\mathrm{Mr}$ lb Aagaard for collecting samples by SCUBA diving and to Ms Jeanne Johansen for technical assistance.

\section{LITERATURE CITED}

American Public Health Association (1975) Standard methods for the examination of water and wastewater, 14 th edn. American Public Health Association, Washington $\mathrm{DC}$

Ankar S, Jansson BO (1973) Effect of an unusual natural temperature increase on a Baltic soft-bottom community. Mar Biol 18:9-18

Bernard C, Fenchel T (1995) Mats of colourless sulphur bacteria. II. Structure, composition of biota and successional patterns. Mar Ecol Prog Ser 128:171-179
Cohen Y, Jørgensen BB, Revsbech NP, Poplawski R (1986) Adaptation to hydrogen sulfide of oxygenic and anoxygenic photosynthesis among cyanobacteria. Appl environ Microbiol 51:398-407

Cussler EL (1989) Diffusion: mass transfer in fluid systems Cambridge University Press, Cambridge., Table 5.2

Fauré-Fremiet E (1951) Assoclations infusoriennes à Beggiatoa. Hydrobiologia 3:65-71

Fenchel T (1969) The ecology of marine microbenthos IV Structure and function of the benthic ecosystem, its chemical and physical factors and the microfauna communities with special reference to the ciliated protozod. Ophelia 6:1-182

Fenchel T (1993) Methanogenesis in marine shallow water sediments: the quantitative role of anaerobic protozoa with endosymbiotic methanogenic bacteria. Ophelia 37 : $67-82$

Fenchel T (1994) Motility and chemosensory behaviour of the sulphur bacterium Thiovulum majus. Microbiology 140 : 3109-3116

Fenchel T, Bernard C (1995) Behavioural responses in oxygen gradients of ciliates from microbial mats. Eur J Protistol 31 (in press)

Fossing $\mathrm{H}$, Gallardo VA, Jørgensen BB, Hüttel M, Nielsen LP, Schulz H, Canfield DE, Forster $S$, Glud RN, Gundersen DE, Küver J, Ramsing NB, Teske $A$, Thamdrup B, Llloa $O$ (1995) Concentration and transport of nitrate by the matforming sulphur bacterium Thioploca. Nature 374 $713-715$

Gallardo VA, Carrasco FD, Roa R, Canete Jl (1995) Ecological patterns in the benthic macrobiota across the continental shelf off central Chile. Ophelia 40:167-188

Garcia-Pichel F, Mechling M, Castenholz RW (1994) Diel migrations of microorganisms within a benthic hypersaline mat community. Appl environ Microbiol 60 $1500-1511$

Glud RN, Gundersen JK, Revsbech NP, Jørgensen BB (1994) Effects on the benthic diffusive boundary layer imposed by microelectrodes. Limnol Oceanogi 39:462-467

Iversen N, Blackburn TH (1981) Seasonal rates of methane oxidation in anoxic marine sediments. Appl environ Microbiol 41:1295-1300

lversen N, Jørgensen BB (1985) Anaerobic methane oxidation rates at the sulfate-methane transition in marine sediments from Kattegat and Skagerrak (Denmark). Limnol Oceanogr 32:804-814

Jannasch HW, Taylor CD. Wirsen CO (1989) Massive natural occurrence of unusual large bacteria (Beggiatoa sp.) at a hydrothermal deep-sea vent site. Nature 342:834-836

Jorgensen BB (1977a) Bacterial sulfate reduction within reduced microniches of oxidized marine sediments. Mar Biol 41:7-17

Jørgensen BB (1977b) Distribution of colorless sulfur bacteria (Beggiatoa spp.) in a coastal marine sediment. Mar Biol 41 : $19-28$

Jargensen BB, Des Marais DJ (1990) The diffusive boundary layer of sediments: oxygen gradients of a microbial mat. Limnol Oceanogr 35:1343-1355

Jorgensen BB, Revsbech NP (1983) Colorless sulfur bactena, Beggiatoa spp. and Thiovulum sp., in $\mathrm{O}_{2}$ and $\mathrm{H}_{2} \mathrm{~S}$ microgradients. Appl environ Microbiol 45:1261-1270

Juniper SK, Brinkhurst RO (1986) Water-column dark $\mathrm{CO}_{2}$ fixation and bacterial-mat growth in intermittently anoxic Saanich Inlet, British Columbia. Mar Ecol Prog Ser 33: $41-50$

Karl DM (1987) Bacterial production at deep-sea hydrothermal vents and cold seeps: evidence for chemosynthetic 
primary production. In: Fletcher M, Gray TRG, Jones JG (eds) Ecology of microbial communities. Cambridge University Press, Cambridge, p 319-360

Kuenen JG (1989) Comparative ecophysiology of the nonphotosynthetic sulfide-oxidizing bacteria. In: Cohen $Y$, Rosenberg $E$ (eds) Microbial mats. American Society of Microbiology, Washington, DC, p 349-365

Kühl M, Jørgensen BB (1992) Microsensor measurements of sulfate reduction and sulfide oxidation in compact microbial communities of aerobic biofilms. Appl environ Microbiol 58:1164-1174

La Rivière JWM, Schmidt K (1992) Morphologically conspicuous sulfur oxidizing eubacteria. In: Balows $A$, Trüper HG, Dworkin $M$, Harder $W$, Schleifer KH (eds) The prokaryotes, Vol IV. Springer Verlag. New York, p 3934-3947

Møller MM, Nielsen LP, Jørgensen BB (1985) Oxygen responses and mat formation by Beggiatoa spp. Appl environ Microbiol 50:573-582

Nelson DC (1989) Physiology and biochemistry of filamentous sulfur bacteria. In: Schlegel HG, Bowien B (eds) Autotrophic bacteria. Springer-Verlag, Berlin, p 219-238

Nelson DC, Jørgensen BB, Revsbech NP (1986a) Growth pat-

This article was submitted to the editor terns and yield of a chemoautotrophic Beggiatoa sp. in oxygen-sulfide microgradients. Appl environ Microbiol 52:225-233

Nelson DC, Revsbech NP, Jørgensen BB (1986b) Microoxicanoxic niche of Beggiatoa spp: microelectrode survey of marine and freshwater strains. Appl environ Microbiol 52; $161-168$

Powell EN, Bright TJ, Woods A, Gittings S (1983) Meiofauna and thiobiosis in the East Flower Garden brine seep. Mar Biol 73:269-283

Rasmussen H, Jørgensen BB (1992) Microelectrode studies of seasonal oxygen uptake in a coastal sediment: role of molecular diffusion. Mar Ecol Prog Ser 81:289-303

Revsbech NP, Jergensen BB (1986) Microelectrodes: their use in microbial ecology. Adv microb Ecol 9:293-352

Revsbech NP, Jørgensen BB, Brix P (1981) Primary production. of microalgae in sediments measured by oxygen microprofile, $\mathrm{H}^{14} \mathrm{CO}_{3}{ }^{-}$fixation, and oxygen exchange methods. Limnol Oceanogr 26:717-730

Vanderborght JP, Billen G (1975) Vertical distribution of nitrate concentration in interstitial water of marine sediments with nitrification and denitrification. Limnol Oceanogr 20:953-961

Manuscript first received: May 9, 1995

Revised version accepted: June 9,1995 